Ciência Florestal, Santa Maria, v. 21, n. 2, p. 363-367, abr.-jun., 2011

\title{
PROPOSTA DE PROTOCOLO PARA EXTRAÇÃO DE DNA DE JABUTICABEIRA
}

PROTOCOL SUGGESTED FOR DNA EXTRACTION OF JABUTICABA TREES

\author{
Moeses Andrigo Danner ${ }^{1}$ Simone Aparecida Zolet Sasso ${ }^{2}$ Juliana Vitória Messias Bittencourt ${ }^{3}$ \\ Idemir Citadin ${ }^{4}$ Marcos Robson Sachet ${ }^{5}$
}

RESUMO

O presente trabalho teve por objetivo adaptar o protocolo descrito por Soto (2001), testar diferentes fontes (tecido vegetal) e estabelecer condições de coleta e pré-tratamento de amostras para extração de DNA de jabuticabeira (Plinia cauliflora (DC.) Berg, Myrtaceae). Utilizaram-se folhas em desenvolvimento, folhas completamente expandidas, câmbio do caule e pecíolo foliar. O protocolo testado pode ser utilizado para extração de DNA de jabuticabeira, pois proporcionou isolamento de DNA de boa qualidade e possibilitou amplificação por meio de PCR ("Reação de Polimerase em Cadeia"). Para evitar a oxidação de folhas é necessário realizar a maceração com nitrogênio líquido.

Palavras-chave: Plinia cauliflora; isolamento de DNA; método CTAB.

\begin{abstract}
This study aimed to adapt the protocol described by Soto (2001), to test different sources (plant tissue) and to establish conditions for collection and pre-treatment of samples for extracting DNA from jabuticaba trees (Plinia cauliflora (DC.) Berg, Myrtaceae). For this purpose, developing and expanded leaves, cambium of the stem and leaf stalk were used. The protocol tested can be used for DNA extraction from jabuticaba trees, because it provided DNA isolation of good quality and allowed the amplification of DNA through of PCR (Polymerase Chain Reaction). The use of liquid nitrogen for the maceration of leaves is necessary to prevent oxidation.
\end{abstract}

Keywords: Plinia cauliflora; DNA isolation; CTAB method.

\section{INTRODUÇÃO}

A jabuticabeira (Plinia cauliflora (DC.) Berg) pertence à família Myrtaceae e é endêmica do centro-sul/sudeste do Brasil (MATTOS, 1983). A produção comercial dessa fruteira é pequena e limitada a determinadas regiões de ocorrência natural. Por isso, a espécie deve ser alvo do melhoramento, conservação de germoplasma e estudos da variabilidade genética, que são pontos de partida para domesticação de qualquer espécie.

Essa fruteira apresenta grande potencial para exploração econômica, em função das características organolépticas de seus frutos (BARROS et al., 1996) e porque contém alto teor de óleos essenciais em suas folhas (APEL et al., 2006) e níveis elevados de antocianinas na casca dos frutos (TEIXEIRA et al., 2008). Seu uso como

1. Engenheiro Agrônomo, Doutorando pela Universidade Federal do Paraná, Extensionista Rural da Epagri. Rua Duque de Caxias, 1002, Bairro Centro, CEP 89990-000, São Lourenço do Oeste (SC). moesesdanner@epagri.sc.gov.br

2. Engenheira Agrônoma, MSc., Professora da Faculdade Mater Dei, Rua Mato Grosso, 200, Bairro Baixada, CEP 85501-200, Pato Branco (PR). iosasso@ibest.com.br

3. Engenheira Agrônoma, Dra ${ }^{\text {. }}$, Universidade Tecnológica Federal do Paraná, Campus Ponta Grossa, Av. Monteiro Lobato, s/n, Km 04, CEP 84016-210, Ponta Grossa (PR). julianavitoria@utfpr.edu.br

4. Engenheiro Agrônomo, Dr., Professor Titular da Universidade Tecnológica Federal do Paraná, Campus Pato Branco, Via do Conhecimento, Km 01, CEP 85530-390, Pato Branco (PR). idemir@utfpr.edu.br

5. Estudante de Agronomia, Universidade Tecnológica Federal do Paraná, Campus Pato Branco, Via do Conhecimento, Km 01, CEP 85530-390, Pato Branco (PR). Bolsista PIBIC/CNPq. marcos.sachet@gmail.com

Recebido para publicação em 5/10/2009 e aceito em 12/08/2010 
planta ornamental também é indicado (DEMATTÊ, 1997). Segundo Balerdi et al. (2006), a jabuticabeira já está sendo testada em cultivos na Flórida, EUA, e em países das Américas Central e do Sul, em razão de seu potencial de cultivo e uso.

Estudos moleculares em populações naturais de espécies da família Myrtaceae foram efetuados para verificar a variabilidade genética, modo de reprodução e estrutura genética (CARDOSO et al., 2000; DRUMMOND et al., 2000; GUSSON et al., 2006). Esses estudos tornam-se importantes para auxiliar na conservação de germoplasma, seleção, melhoramento genético e manejo dessas espécies. Porém, apenas um trabalho com caracterização molecular em jabuticabeira foi encontrado na literatura (PEREIRA et al., 2005).

Para a aplicação de técnicas moleculares, primeiramente é necessária a obtenção de metodologias adequadas para o isolamento de ácido desoxirribonucléico (DNA), com bom rendimento e qualidade, especialmente em espécies em que poucos estudos foram realizados nesse sentido e, portanto, não possuam adequação de técnicas, como é o caso da jabuticabeira. O DNA isolado deve estar livre de contaminantes, como polissacarídeos, proteínas e substâncias fenólicas. Nesse sentido, a forma de coleta e acondicionamento dos tecidos vegetais, assim como seu manuseio durante extração, são fundamentais (MAZZA e BITTENCOURT, 2000). A maioria dos protocolos de extração de DNA de plantas descritos na literatura utilizam o método baseado no detergente catiônico CTAB (cationic hexadecyl trimetyl ammonium bromide), com algumas modificações de acordo com características da espécie. Por isso, ajustes de protocolos são fundamentais, de forma a desenvolver um procedimento simples, rápido e de baixo custo, proporcionando a extração de DNA de qualidade adequada para diversas análises moleculares (MOLINARI e CROCHEMORE, 2001; KOTCHONI e GACHOMO, 2009).

O objetivo desse trabalho foi adaptar o protocolo descrito por Soto (2001), testar diferentes fontes (tecido vegetal) e estabelecer condições de coleta e pré-tratamento de amostras para extração de DNA de jabuticabeira (Plinia cauliflora).

\section{MATERIAL E MÉTODO}

Oexperimento foi conduzido no Laboratório de Biologia Molecular do Centro de Biotecnologia Agroindustrial do Paraná (Cenbapar) e Universidade
Tecnológica Federal do Paraná (UTFPR), Campus Pato Branco.

As seguintes fontes de tecidos vegetais foram testadas: (1) folhas em desenvolvimento, (2) folhas completamente expandidas, (3) câmbio do caule e (4) pecíolos foliares. Todas foram coletadas de uma mesma planta de Plinia cauliflora, com 12 anos de idade. As folhas em desenvolvimento (coloração avermelhada), as folhas completamente expandidas (coloração verde-escuro) e os pecíolos foliares foram coletados e submetidos, imediatamente, à extração de DNA. Preliminarmente testou-se a maceração diretamente em tampão de extração (2\% CTAB; $1,4 \mathrm{M} \mathrm{NaCl} ; 20$ mM EDTA; $100 \mathrm{mM}$ Tris- $\mathrm{HCl} \mathrm{pH} 8,0)$ ou com a adição de nitrogênio líquido. O câmbio vegetal foi coletado do caule da planta e imediatamente colocado em microtubo, contendo $800 \mu \mathrm{L}$ de tampão de extração. O câmbio foi macerado com adição de $600 \mu \mathrm{L}$ de tampão de extração. Para extração foram utilizados entre 0,20 e $0,30 \mathrm{~g}$ de tecido vegetal de cada fonte.

Utilizou-se protocolo modificado de Soto (2001), contendo os seguintes passos: 1) trituração do material vegetal com nitrogênio líquido ou com o tampão de extração; 2) adição de $600 \mu \mathrm{L}$ de tampão de extração $\mathrm{CTAB}$ em um microtubo de $1,5 \mathrm{~mL}$, à exceção do microtubo para a amostra do câmbio, que já continha CTAB; 3 ) transferência do pó (oriundo do macerado) ao microtubo, com auxílio de espátula; 4) solubilização e homogeneização da suspensão em banho-maria à $65^{\circ} \mathrm{C}$ durante 30 minutos, com agitação manual a cada 10 minutos; 5) após deixar a suspensão chegar à temperatura ambiente, adição de $800 \mu \mathrm{L}$ do solvente orgânico clorofórmio:álcool isoamílico, 24:1 (CIA); 6) agitação manual por cinco minutos; 7) centrifugação durante cinco minutos a $18.643 \mathrm{~g}$, em temperatura ambiente; 8) transferência da fase aquosa (sobrenadante) para um novo microtubo; 9) adição de um volume de CIA; 10) repetição das etapas 6 e 7; 11) coleta do sobrenadante e transferência para novo microtubo; 12) adição de 2,5 volumes de etanol ( $96 \%)$ gelado e permanência por 20 minutos em freezer; 13) centrifugação a 18.643 g por 7 minutos; 14) eliminação do sobrenadante e recuperação do pellet; 15) ressuspensão do pellet em $100 \mu \mathrm{L}$ de TE $1 \mathrm{x}$ (Tris $\mathrm{HCl} 1 \mathrm{M} \mathrm{pH} \mathrm{8,0;} \mathrm{EDTA} \mathrm{0,5} \mathrm{M).}$

Para a verificação da qualidade do DNA, uma alíquota de $5 \mu \mathrm{L}$ de cada amostra foi analisada através de eletroforese em gel de agarose a 1,0\%. A corrida eletroforética foi realizada por 40 minutos a $3 \mathrm{~V} / \mathrm{cm}$. Utilizou-se marcador de peso molecular

Ci. Fl., v. 21, n. 2, abr.-jun., 2011 
100 bp ladder. Testou-se também amplificação, por meio de reação em cadeia da polimerase (PCR), do DNA isolado de folhas jovens maceradas com auxílio de nitrogênio líquido. $\mathrm{O}$ produto dessa reação foi visualizado em gel de agarose a $1,5 \%$, submetido à corrida eletroforética durante 120 minutos a $3 \mathrm{~V} / \mathrm{cm}$, com 10 primers RAPD (polimorfismo de DNA amplificado ao acaso) (Tabela 1). Em ambos os casos, após a corrida eletroforética, o DNA foi corado brometo de etídio $\left(0,5 \mu \mathrm{g} \mathrm{mL}^{-1}\right)$ por 10 minutos, o DNA isolado foi visualizado em transluminador e fotodocumentado com equipamento Vilber Lourmat ECX-20.M.

TABELA 1: Primers RAPD utilizados na amplificação do DNA de folhas em desenvolvimento de jabuticabeira (Plinia cauliflora).

TABLE 1: Primers RAPD utilized in the amplification of DNA of development leaves of jabuticaba tree (Plinia cauliflora).

\begin{tabular}{cc}
\hline Primers & Sequência $\left(5^{\prime}-3^{\prime}\right)$ \\
\hline C3 & GGGGGTCTTT \\
C4 & CCGCATCTAC \\
C5 & GATGACCGCC \\
C6 & GAACGGACTC \\
C7 & GTCCCGACGA \\
C8 & TGGACCGGTG \\
C9 & CTCACCGTCC \\
C10 & TGTCTGGGTG \\
C11 & AAAGCTGCGG \\
C12 & TGTCATCCCC \\
\hline
\end{tabular}

\section{RESULTADOS E DISCUSSÃO}

De forma geral, o protocolo proposto nesse trabalho proporcionou o isolamento de DNA de boa qualidade de todas as fontes testadas, não havendo degradação e contaminação (Figura 1), exceto para a extração utilizando-se folhas em expansão maceradas diretamente em tampão CTAB (2\%), pois o DNA se apresentou degradado e contaminado, o que pode ser em virtude da oxidação de compostos fenólicos. Isso impossibilita amplificações por meio de técnicas de PCR, comprometendo a reprodutibilidade das análises (ROMANO e BRASILEIRO, 1999). Porém, apenas a inclusão de nitrogênio líquido durante a maceração, que permitiu o rápido congelamento do tecido vegetal, evitou a degradação do DNA das amostras, o que torna a extração de DNA de jabuticabeira rápida e barata, características do protocolo utilizado.

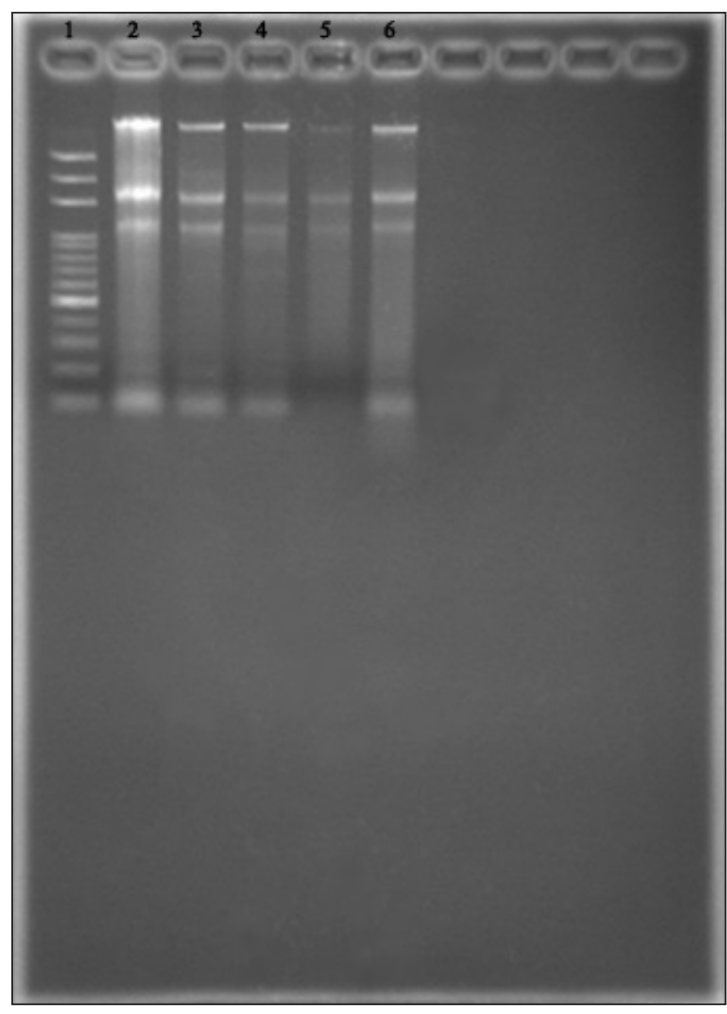

FIGURA 1: Qualidade de DNA de tecidos vegetais de jabuticabeira (Plinia cauliflora). 1: marcador de peso molecular $100 \mathrm{bp}$ ladder; 2: folhas em desenvolvimento maceradas com CTAB (2\%); 3: folhas em desenvolvimento maceradas com nitrogênio líquido; 4: folhas expandidas maceradas com nitrogênio líquido; 5: câmbio do caule macerado com CTAB (2\%); 6: pecíolos foliares macerados com nitrogênio líquido. Pato Branco, Paraná, Brasil.

FIGURE 1: DNA quality of plant tissue of jabuticaba tree (Plinia cauliflora). 1: DNA marker 100 bp ladder; 2: developing leaves ground in $\mathrm{CTAB}$ $(2 \%) ; 3$ : developing leaves ground in liquid nitrogen; 4: expanded leaves ground in liquid nitrogen; 5 : cambium of the stem ground in CTAB (2\%); 6 : leaf stalk ground in liquid nitrogen. Pato Branco, Paraná, Brazil. 
O DNA obtido de folha jovem macerada em nitrogênio líquido mostrou-se amplificável por meio de PCR (Figura 2). Observou-se que dos 10 primers RAPD testados, dois deles se destacaram, C5 (5' GATGACCGCC 3') e C12 (5' TGTCATCCCC 3'). Estes apresentaram o maior número de bandas polimórficas, podendo ser selecionados para posteriores análises moleculares em jabuticabeira. Um número maior de marcadores RAPD para jabuticabeira devem ser selecionados em próximos experimentos.

A extração de DNA de folhas de jabuticabeira foi realizada por Pereira et al. (2005), utilizando metodologia modificada de Lodhi (1994), a qual inclui a adição de polivinilpirolidona, $\mathrm{NaCl} 5$ $\mathrm{M}$ e RNAse no processo, além da necessidade de

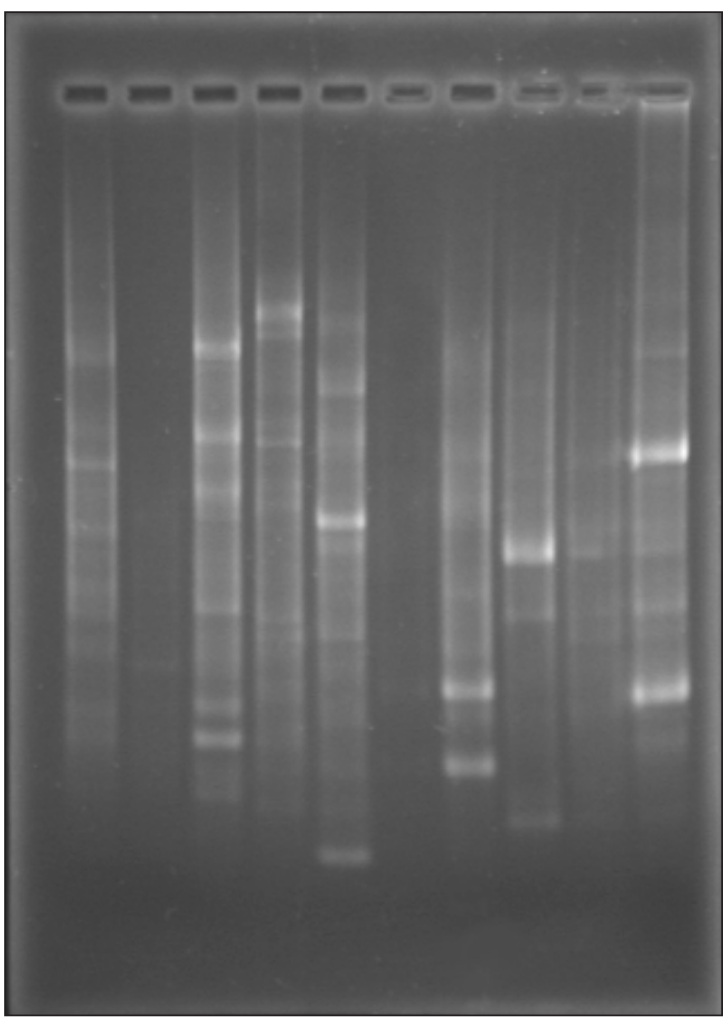

FIGURA 2: Perfil eletroforético de 10 primers RAPD usando DNA extraído de folhas em desenvolvimento de jabuticabeira (Plinia cauliflora), amplificados através de PCR. Pato Branco, Paraná, Brasil.

FIGURE 2: Electrophoretic profile of ten primers RAPD using DNA extracted from developing leaves of jabuticaba tree (Plinia cauliflora), amplified by PCR. Pato Branco, Paraná, Brazil. centrífuga refrigerada, o que a torna mais cara e morosa que a técnica descrita no presente trabalho. Assim, como no presente trabalho houve a extração de DNA de boa qualidade e amplificável por meio de técnica de PCR, a utilização dessa metodologia reduz os custos de análises moleculares em jabuticabeira.

Observou-se também que o câmbio do caule de jabuticabeira escurece rapidamente, provavelmente por causa da oxidação por compostos fenólicos. Portanto sua conservação deve ser efetuada imediatamente após coleta, colocando-o em tampão CTAB (2\%). Esse método de coleta do câmbio proporcionou extração de DNA de boa qualidade, porém a quantidade foi inferior às outras fontes testadas, demonstrada pela intensidade da banda gerada (Figura 1). Para aumentar a quantidade de DNA extraído, sugere-se utilizar maior quantidade de tecido de câmbio em relação ao utilizado para a maceração nesse experimento ( $>$ $0,25 \mathrm{~g}$ ). Salienta-se que o câmbio vegetal dispensa uso de nitrogênio líquido para maceração, facilita a coleta em populações naturais e o manuseio sob armazenamento.

O protocolo testado pode ser utilizado para extração de DNA de jabuticabeira, abrindo a perspectiva para análises genéticas utilizando marcadores moleculares, para verificar a dispersão da variabilidade genética de populações e estimar o modo de reprodução da espécie.

\section{CONCLUSÕES}

Os resultados encontrados no presente experimento permitem concluir que:

O protocolo testado pode ser utilizado em jabuticabeira, pois proporciona a extração de DNA de boa qualidade;

Os primers RAPD C5 (5' GATGACCGCC 3') e C12 (5' TGTCATCCCC 3') podem ser selecionados para análises moleculares em jabuticabeira;

É necessária a adição de nitrogênio líquido na maceração de folhas de jabuticabeira, o qual otimiza a extração e reduz a presença de compostos indesejados.

\section{REFERÊNCIAS BIBLIOGRÁFICAS}

APEL, M. A. et al. Essential oil composition of four Plinia species (Myrtaceae). Flavour and Fragrance Journal, Chichester, v. 21, n. 3, p. 565- 
567, 2006.

BALERDI, C. F. et al. Jaboticaba (Myrciaria cauliflora, Berg.): a delicious fruit with an excellent market potential. Proceedings of the Florida State Horticultural Society, Gainesville, v. 119, p. 6668, 2006.

BARROS, R. S. et al. Changes in nonstructural carbohydrates in developing fruit of Myrciaria jaboticaba. Scientia Horticulturae, Amsterdam, v. 66, n. 3-4, p. 209-215, 1996.

CARDOSO, S. R. S. et al. Genetic differentiation of Euterpe edulis Mart. populations estimated by AFLP analysis. Molecular Ecology, Oxford, v. 9, n. 11, p. 1753-1760, 2000.

DEMATTÊ, M. E. S. P. Ornamental use of Brazilian Myrtaceae. Acta Horticulturae, Leuven, n. 452, p. 143-179, 1997.

DRUMMOND, R. S. M. et al. Genetic analysis and conservation of 31 surviving individuals of a rare New Zealand tree, Metrosideros bartlettii (Myrtaceae). Molecular Ecology, Oxford, v. 9, n. 8, p. 1149-1157, 2000.

GUSSON, E. et al. Sistema de reprodução em populações de Eschweilera ovata (Cambess.) Miers. Revista Árvore, Viçosa, v. 30, n. 4, p. 491502, 2006.

KOTCHONI, S. O.; GACHOMO, E. W. A rapid and hazardous reagent free protocol for genomic DNA extraction suitable for genetic studies in plants. Molecular Biology Reports, Worcester, v. 36, n. 6, p. 1633-1636, 2009.
LODHI, M. A. et al. A simple and efficient method for DNA extraction from grapevine cultivars and Vitis species. Plant Molecular Biology Reporter, Athens, v. 12, n. 1, p. 6-13, 1994.

MATTOS, J. R. Fruteiras nativas do Brasil: jaboticabeiras. São Paulo: Nobel, 1983. 92 p.

MAZZA, M. C. M.; BITTENCOURT, J. V. M. Extração de DNA de tecido vegetal de Araucaria angustifolia (Araucariaceae). Boletim de Pesquisa Florestal, Colombo, n. 41, p. 12-17, 2000.

MOLINARI, H. B.; CROCHEMORE, M. L. Extração de DNA genômico de Passiflora spp. para análises PCR-RAPD. Revista Brasileira de Fruticultura, Jaboticabal, v. 23, n. 2, p. 447-450, 2001.

PEREIRA, M. et al. Morphologic and molecular characterization of Myrciaria spp species. Revista Brasileira de Fruticultura, Jaboticabal, v. 27, n. 3, p. 507-510, 2005.

ROMANO, E.; BRASILEIRO, A. C. M. Extração de DNA de plantas. Biotecnologia, Ciência e Desenvolvimento, Brasília, v. 2, n. 9, p. 40-43, 1999.

SOTO, B. Análisis molecular de poblaciones segregantes de Pinus radiata. 2001. $78 \mathrm{f}$. Monografia (Graduação em Engenharia Florestal)Universidad Católica de Temuco, Temuco-Chile, 2001.

TEIXEIRA, L. N. et al. Comparação de métodos para quantificação de antocianinas. Ceres, Viçosa, v. 55 , n. 4, p. 297-304, 2008. 